\title{
Distribution patterns of Recent pteropods in surface sediments of the western continental shelf of India
}

\author{
ARUN DEO SINGH ${ }^{1}$, NEELAKANTAN RAVINDRAN NISHA ${ }^{1}$ \& THADICKAL VISWANATHAN JOYDAS ${ }^{2}$ \\ ${ }^{1}$ Department of Marine Geology \& Geophysics, School of Marine Sciences, Cochin University of Science and Technology, Cochin, Kerala, \\ India 682016 (e-mail: arundeosingh@yahoo.com) \\ ${ }^{2}$ Department of Marine Biology, School of Marine Sciences, Cochin University of Science and Technology, Cochin, Kerala, India 682016
}

\begin{abstract}
This paper is the first contribution to the knowledge of pteropods in surficial sediments of the entire western continental shelf of India. Both qualitative and quantitative analyses of pteropod assemblages were carried out on 50 coarse fractions $(>125 \mu \mathrm{m})$ of topmost portions of grab samples recovered along 12 transects covering the inner shelf to the upper slope (30-200 m water depths). The distribution of eight significant species was mapped. The resultant maps were correlated with the bathymetric, hydrographic and aragonite preservation conditions in the investigated area. This study reveals a bathymetric control over the distribution of Limacina inflata, Creseis acicula and Creseis chierchiae across the shelf. Furthermore, a marked difference in vertical salinity gradient from south to north along the shelf appears to have a profound influence on the abundance of these species. The pteropod shells in sediments of the northern offshore region with anoxic bottom conditions are generally well preserved, unlike the southern region, where oxygen concentration of the bottom water is relatively high enough to cause dissolution or even elimination of many shells of the most susceptible pteropods like $C$. acicula and $C$. chierchiae. The variation in the intensity of the oxygen minimum zone along the western continental shelf of India has significant influence upon the distribution pattern of Clio convexa. J. Micropalaeontol. 24(1): 39-54, May 2005.
\end{abstract}

KEYWORDS: Recent Pteropods, Arabian Sea, Indian Shelf, spatial distribution, dissolution

\section{INTRODUCTION}

Pteropods are widely distributed in oceans and marginal seas but abundant in those shallow basins and along those continental margins with high temperature and salinity (Sverdrup et al., 1942). They have been used extensively in the reconstruction of Quaternary palaeoceanographic and palaeoclimatic history of the Red Sea, the Gulf of Aden, the Gulf of Aqaba and the Mediterranean Sea (Herman, 1968, 1971; Chen, 1969; Deuser et al., 1976; Reiss et al., 1980; Almogi-Labin, 1982; Ivanova, 1982, 1985; Luz \& Reiss, 1983; Winter et al., 1983; AlmogiLabin et al., 1986, 1991, 1998). A knowledge of the regional distribution pattern of recent pteropods and its correlation with the physico-chemical conditions of the water column is essential in order to investigate their potential as indicators of environmental change. Several studies have been carried out on living, as well as dead, pteropod assemblages in marginal seas to understand the relationships between their distribution pattern and environmental conditions (Rosenberg-Herman, 1965; Reiss et al., 1980; Weikert, 1982; Almogi-Labin, 1984; AurasSchudnagies et al., 1989). Less effort has been directed towards the investigation of Arabian Sea pteropod populations. Sakthivel $(1969,1973 a, b)$ made attempts to study living pteropods of the Arabian Sea, the Bay of Bengal and the southwestern parts of the Indian Ocean. Auras-Schudnagies et al. (1989) recorded the distribution of pteropods in water and surface sediments of the northwestern Arabian Sea. These studies on Arabian Sea pteropods were generally limited to deeper regions. There is little knowledge available on the distribution of pteropods in marginal sediments of the Arabian Sea, where they occur in abundance. The continental margins are the best areas for high-resolution palaeoenvironmental studies (as the sedimentation rates are much higher than in the open ocean). Additionally, pteropods constitute one of the main biotic carbonate components in the shelf sediments of the west coast of India. A preliminary investigation on recent pteropods was made by Herman \& Rosenberg (1969) and Herman (1971) using ten dredge samples from the northern part of the western continental shelf (between $17^{\circ} \mathrm{N}$ and $24^{\circ} \mathrm{N}$ Lat.). Recently, Singh \& Rajarama (1997) and Singh et al. $(1998,2001)$ studied pteropod assemblages in a few core-top samples from a small area of the southwestern shelf (between $11^{\circ} \mathrm{N}$ and $12^{\circ} \mathrm{N}$ Lat.). Previous studies lacked adequate samples and large coverage along the western continental shelf of India. The objectives of this investigation are (1) to record the absolute abundance of total pteropods and map the distribution of significant species and (2) to document pattern variation in pteropod assemblages in response to hydrographic and bathymetric conditions along the entire western continental shelf of India. The pteropod data generated in the present study can be used as an analogue to deduce past changes based on the faunal variation in sedimentary records.

\section{PHYSIOGRAPHY AND OCEANOGRAPHIC SETTING}

The western continental shelf of India (Fig. 1) covers an area of about $310000 \mathrm{~km}^{2}$ and stretches between $7^{\circ} \mathrm{N}$ and $24^{\circ} \mathrm{N}$ Lat. (Rao \& Wagle, 1997). The width of the shelf is greater in the north, narrowing towards the south. The Saurashtra coast (between $21^{\circ} \mathrm{N}$ and $22^{\circ} \mathrm{N}$ Lat.) has an average shelf width of $120 \mathrm{~km}$. From Bombay to Ratnagiri, the shelf width is about $280 \mathrm{~km}$. Further south, between Ratnagiri and Mangalore, the average width lowers to $80 \mathrm{~km}$. The depth of the shelf edge along the western continental shelf varies between $90 \mathrm{~m}$ and $200 \mathrm{~m}$ (Ramsamy \& Rao, 1980). The continental slope is steep in the north and gentle in the south. 


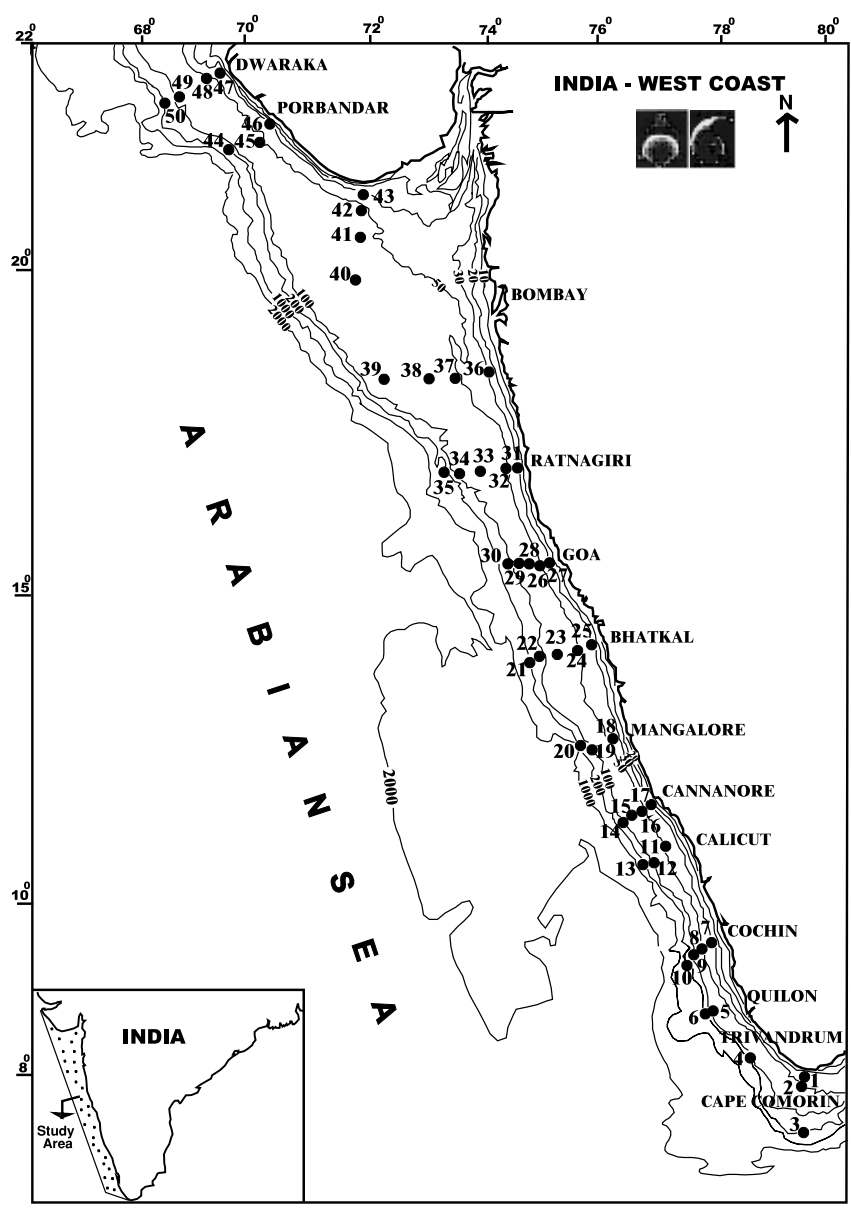

Fig. 1. Map of the sample locations. Bathymetric contours are shown in metres.

The study area is influenced by both the southwestern and northeastern monsoons. During the SW monsoon, sporadic upwelling occurs in the eastern Arabian Sea off southwest India (Wyrtki, 1971; Naidu et al., 1999). The NE monsoon results in a weak upwelling in the northeastern Arabian Sea. The Arabian Sea waters off the northwest Indian coast are more saline than the surface waters off the southwestern coast. The coastal surface currents move southward during the SW monsoon. The North Equatorial Current (low-salinity water) sets in during the NE monsoon and moves upward into the southeastern Arabian Sea. The annual mean sea-surface salinity and temperature of shelf-slope waters vary approximately between 34\%o and 36\%0 and $28^{\circ} \mathrm{C}$ and $26^{\circ} \mathrm{C}$, respectively, from south to north along the coast (Fig. 2). A seasonal variation in salinity exists near the southernmost part of India. In northern summer, salinities are recorded between $34.5 \%$ and $35.5 \%$, but, in northern winter, low salinity water $(<33 \%$ ) extends from the Bay of Bengal up to some distance off the west coast of India (Darbyshire, 1967; Wyrtki, 1971). The southern region is characterized by a marked vertical salinity gradient, whereas the difference between the surface and subsurface salinities in northern waters is very low. A low oxygen concentration occurs below $100 \mathrm{~m}$, decreasing rapidly downwards in the water column. The oxygen concentration at $200 \mathrm{~m}$ depth is about $0.15 \mathrm{ml} \mathrm{O}_{2} 1^{-1}$ in the south, decreasing northward to $<0.05 \mathrm{ml} \mathrm{O}_{2} 1^{-1}$.
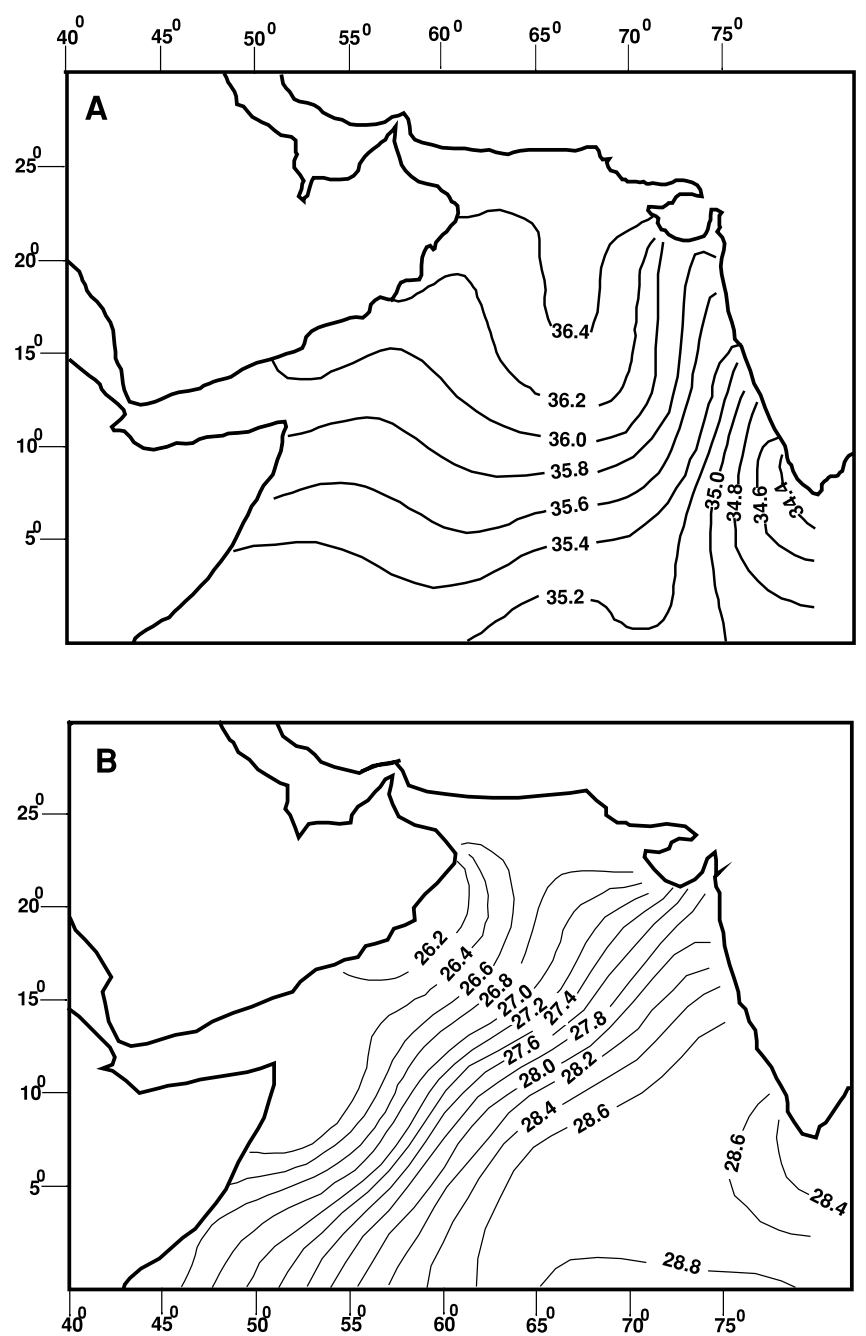

Fig. 2. Annual mean sea-surface (A) salinity and (B) temperature in the Arabian Sea (contoured using $1^{\circ} \times 1^{\circ}$ digital data from Levitus (1982)).

\section{Sediment characteristics}

Two major sedimentary units can be identified on the shelf. In general, the inner shelf region is covered by fine sediments (clayey silt), except for the southernmost part where coarse sediments dominate. The outer shelf is covered by sand-silt-clay and clay with silty clay. The shelf sediments comprise both biogenic and non-biogenic elements. Biogenic skeletal debris content increases towards the outer shelf-upper slope. Foraminifera and pteropods are the dominant constituents of the biogenic skeletal debris in the coarse fraction of the outer shelf sediments. The inner shelf calcareous assemblages are dominated by benthic foraminifera, remains of bryozoans, pelecypods and gastropods. The minor components include echinoids, sponge spicules and algal fragments. The outer shelf sediments along the northern part of the west coast (north of $18^{\circ} \mathrm{N}$ Lat.) also consist of non-skeletal components (ooids, grapestones, pelletoids and lithoclasts) (Hashimi \& Nair, 1976).

\section{MATERIAL AND METHODS}

Fifty surficial sediment samples from the entire western continental shelf of India, along the twelve transects covering the 
inner shelf to the upper slope (30 $\mathrm{m}$ to $200 \mathrm{~m}$ water depths), were collected using a Smith-McIntyre grab sampler during the FORV Sagar Sampada Cruise no. 162 in February-March 1998 (Fig. 1). The hydrographic parameters (temperature, salinity and dissolved $\mathrm{O}_{2}$ (DO)) of surface and bottom waters were measured at each sampling station (Table 1). The grab was carefully operated so that negligible loss of surface sediment took place. The surface sediment layer $(1 \mathrm{~cm}$ thick) was scooped off and kept for this study. About $15 \mathrm{~g}$ of dried material was washed through a $63 \mu \mathrm{m}$ screen and dried. Dry residue larger than $63 \mu \mathrm{m}$ was weighed and sieved through a $125 \mu \mathrm{m}$ screen. Census counts of pteropods were made on $>125 \mu \mathrm{m}$ fractions. Large samples were split into suitable aliquots of approximately 250-300 pteropod specimens. Those samples containing a low number of pteropod shells were used completely for counting. The absolute abundance was estimated for $1 \mathrm{~g}$ dry sediment (Table 2). The relative abundance of individual species was also recorded as a percent of the total pteropod population (Table 2). Distribution maps for abundant species were prepared (Figs 3-14). Different contour intervals were selected for different species to highlight meaningful distribution patterns, these contours were extrapolated at some places where data were insufficient. The taxonomy of Van der Spoel (1967) and Bé \& Gilmer (1977) was followed.

In order to obtain information on the preservation state of pteropods, shell transparency (Byrne et al., 1984; Almogi-Labin et al., 1986) and fragmentation (Gerhardt et al., 2000) were studied in three of the most delicate abundant species, namely Creseis chierchiae, C. acicula and Limacina inflata (Table 3). Shells were grouped into two categories: (i) transparent indicating highest preservation; and (ii) opaque-white - reflecting corrosion and dissolution. The percentage abundances of damaged shells (at least $50 \%$ of the shell existing) in populations of these species were estimated to record the degree of dissolution on susceptible pteropods. Although care was taken to avoid mechanical damage of the shells during sample preparation, the percentage of broken shells was estimated only when at least twenty particles (whole and damaged) were available.

\section{RESULTS AND DISCUSSION}

The distribution of pteropods is controlled primarily by the upper water masses of the oceans (Sverdrup et al., 1942). Previous studies on living pteropods reveal that the distribution of pteropods in the water column is greatly influenced by the variations in hydrographic conditions and diurnal vertical migration in certain species (Chen \& Bé, 1964; Van der Spoel, 1967; Bé \& Gilmer, 1977; Wormuth, 1981; Almogi-Labin et al., 1988). Because of their larger size and mass, pteropod tests have a higher settling velocity, promoting deposition close to the organism's habitat (Vinogradov, 1961; Bathmann et al., 1991; Jasper \& Deuser, 1993; Kalberer et al., 1993). Investigations on the population dynamics and distribution of modern pteropods suggest conspicuous similarities between living assemblages and the thanatocoenosis in surface sediments (Weikert, 1982, 1987; Almogi-Labin, 1984; Auras-Schudnagies et al., 1989). Hence, the parameters determining the abundance of these organisms in modern sediments can be used to reconstruct more accurately the past conditions from the fossil record.
A total of 24179 pteropod individuals were picked from fifty samples, identified and counted (Table 2). The pteropod assemblages are characterized by low diversity and composed of both epipelagic and mesopelagic forms. In total, 13 species were identified (Plates 1 \& 2). Limacina inflata (d'Orbigny), L. trochiformis (d'Orbigny), Creseis chierchiae (Boas), C. acicula (Rang), C. virgula (Rang) [forma virgula (Rang) and forma conica Escholtz], Clio convexa (Boas), Cavolinia longirostris (de Blainville) and Diacria quadridentata (de Blainville) together form $99 \%$ of the pteropod population. Other rare species are Diacria trispinosa (de Blainville), Clio pyramidata Linnaeus, Cavolinia sp., Limacina bulimoides (d'Orbigny) and Styliola subula (Quoy and Gaimard).

\section{Preservation state of pteropod shells}

Pteropod shells in sediment samples recovered from $<100 \mathrm{~m}$ depth are mostly intact and transparent, indicating good preservation. However, the state of aragonite preservation in sediments lying under oxygen-deficient waters (below $100 \mathrm{~m}$ water depth) along the western continental shelf of India varies significantly from south to north (Table 3 ). The preservation records (transparent vs opaque-white shells, percentage of broken shells) of three most delicate species determined at $100 \mathrm{~m}$ and $200 \mathrm{~m}$ water depths reveal that $C$. acicula and C. chierchiae are more easily dissolved than $L$. inflata. In most of the examined samples, except those from the southernmost region, $>98 \%$ shells of L. inflata are found to be intact. Moreover, the opaque-white shells comprise the major portion of the L. inflata population, which suggests corrosion resulting in loss of shell transparency. Aragonite dissolution leading to shell destruction and fragmentation appears to be prominent on Creseis shells. In general, a lower abundance of transparent shells of $L$. inflata and a higher concentration of broken shells of Creseis in samples at $200 \mathrm{~m}$ isobath is noted, as opposed to those at $100 \mathrm{~m}$ which indicate poor aragonite preservation in deeper regions. A significant number of damaged shells of Creseis (chierchiae and acicula) recorded from the southern offshore region reflects the severe affects of dissolution on these most delicate pteropods. This may have even resulted in the elimination of many of these shells from the sediments. This dissolution effect was also noticed on the shells of $L$. inflata from the southern region, but not up to the extent observed in Creseis. Creseis shells in northern offshore sediments are mostly intact and many of them are transparent, suggesting a better state of preservation.

\section{Absolute pteropod abundance}

The total distribution pattern of pteropods in surface sediments along the western continental shelf of India is presented in Figure 3. In general, the absolute abundance increases across the shelf with the water depth. A significant increase in the numerical abundance of pteropods is recorded from deepest stations $(200 \mathrm{~m})$ of all the transects across the shelf-upper slope, which varies from a minimum 310 specimens $\mathrm{g}^{-1}$ dry sediment in the south (off Cape Comorin), to a maximum of 2985 specimens $\mathrm{g}^{-1}$ dry sediment in the north (off Dwarka) (Table 2). Overall, the pattern of pteropod abundance at $200 \mathrm{~m}$ isobath exhibits an increasing trend from $13^{\circ} \mathrm{N}$ northward (Table 2). At shallower stations ( $<200 \mathrm{~m}$ depths), pteropod concentration is conspicuously lower in the southern region as compared to the 
A. D. Singh et al.

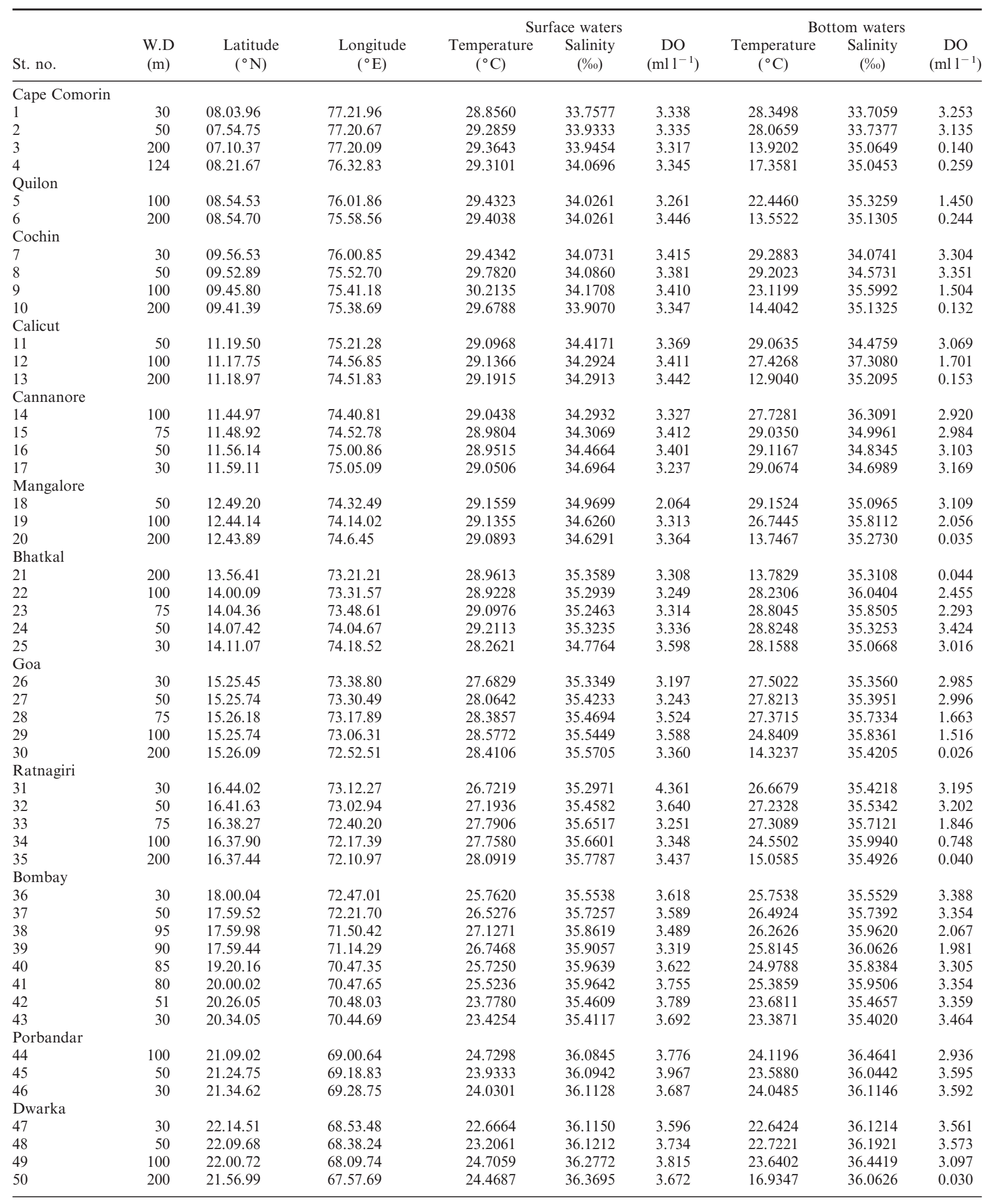

Surface sediments were collected at 50 stations (on 12 transects) along the western continental shelf of India.

Table 1. Bathymetric and hydrographic details of sample locations. 


\section{Recent Indian pteropods}

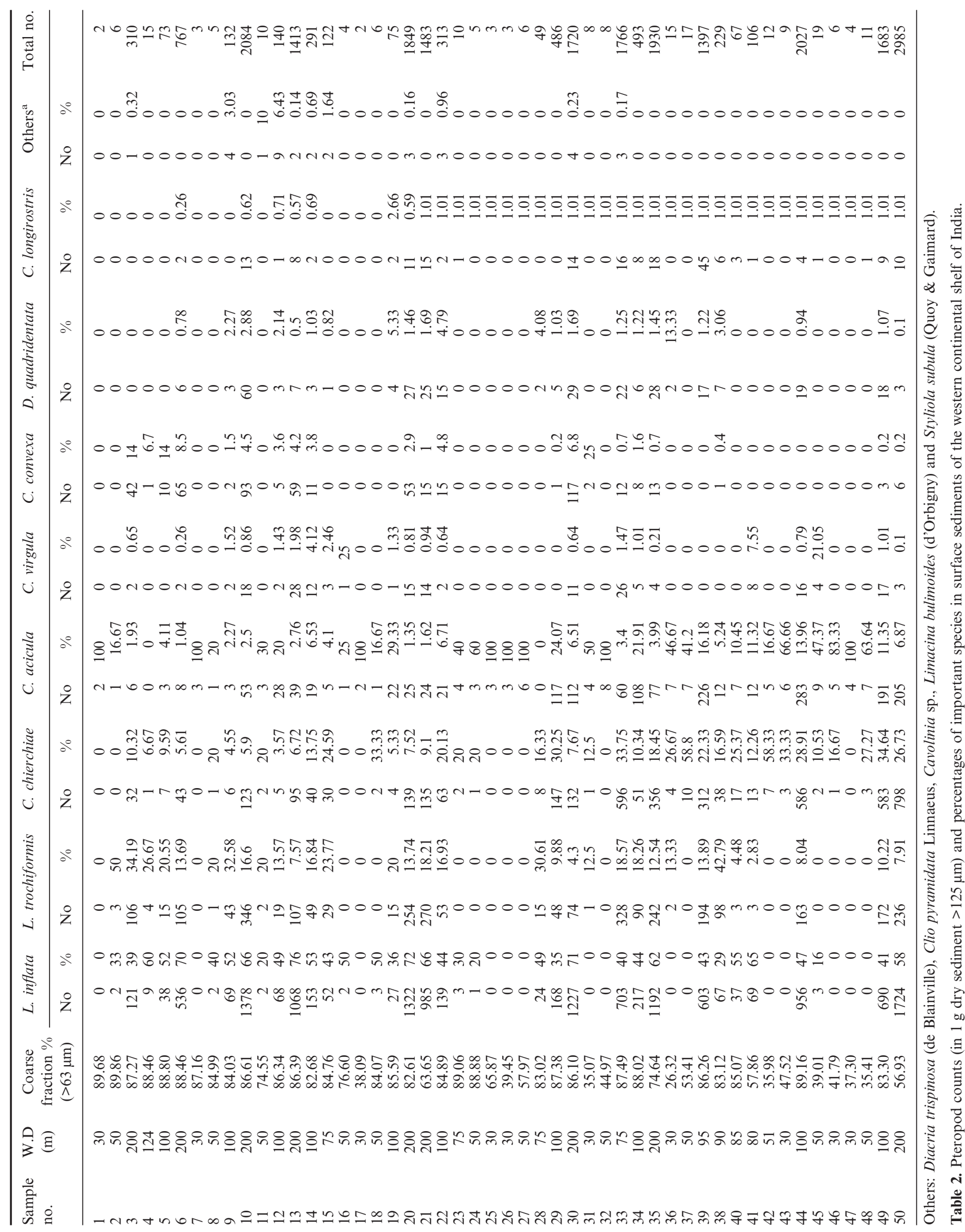


A. D. Singh et al.

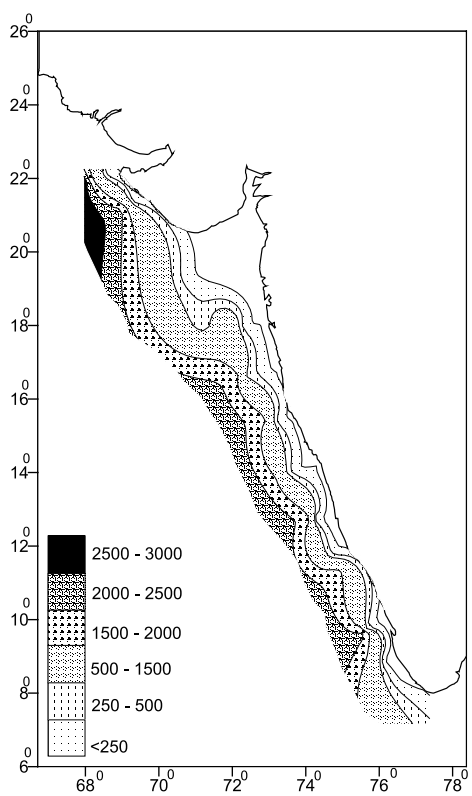

Fig. 3. Absolute abundance of pteropods $(>125 \mu \mathrm{m})$ per gram dry sediment along the western continental shelf of India.

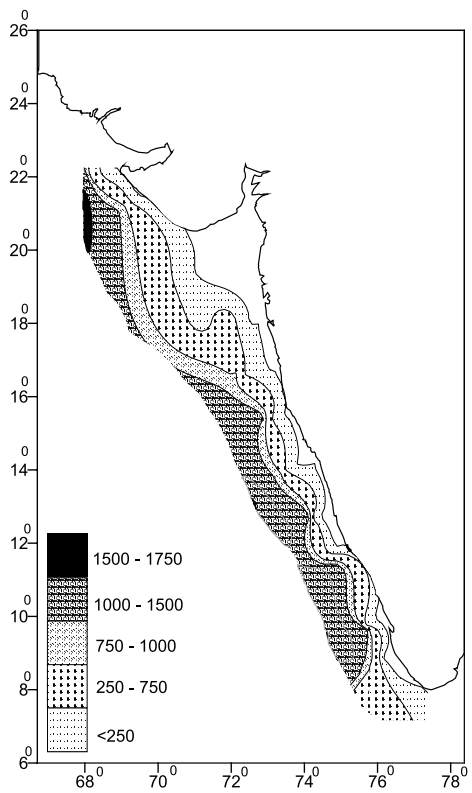

Fig. 4. Absolute abundance of Limacina inflata in surface sediments of the western continental shelf of India.

northern part of the shelf. In a few samples from the middle shelf between $16^{\circ} \mathrm{N}$ and $18^{\circ} \mathrm{N}$, the numerical abundance of pteropods is found to be relatively very high (Table 2).

The absolute abundance of pteropods in marine sediments is related primarily to (i) the production of pteropods in the water column, (ii) the depositional rate and the dissolution of shells on the sea floor and (iii) the sediment accumulation rate (dilution effect). The spatial difference in sedimentation rate can be one of the probable factors influencing the abundance pattern of pteropods in the investigation area. There are a few publications reporting sedimentation rates along the western continental

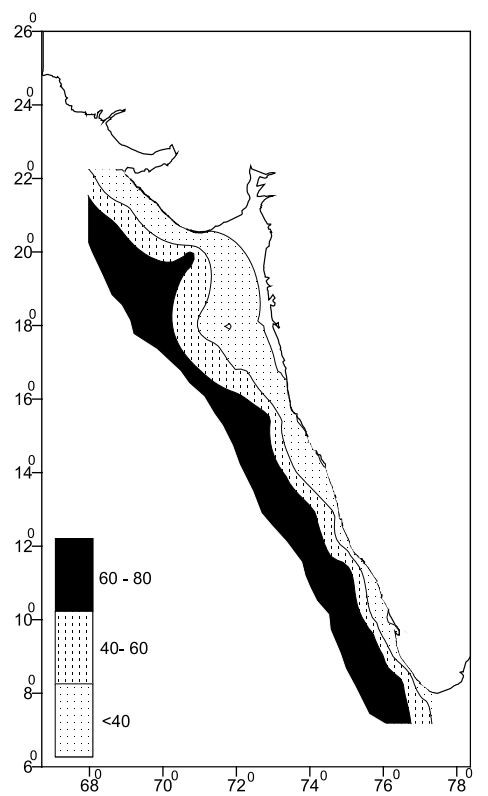

Fig. 5. Distribution of relative abundance (\%) of Limacina inflata in surface sediments of the western continental shelf of India.

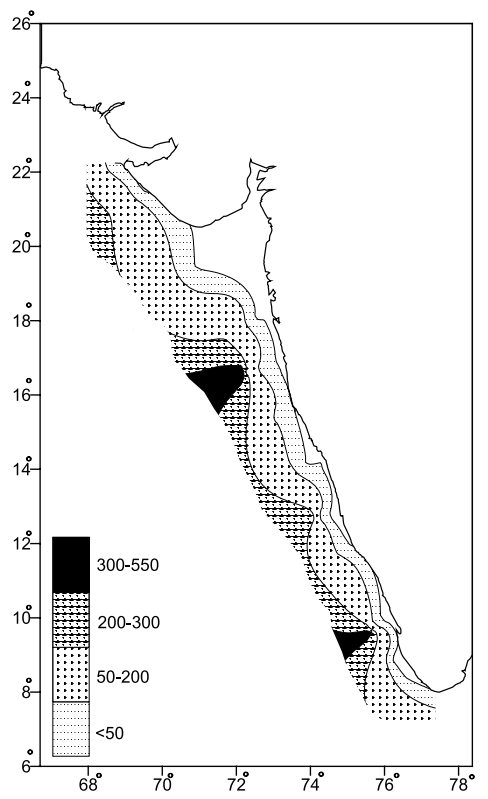

Fig. 6. Absolute abundance of Limacina trochiformis in surface sediments of the western continental shelf of India.

margin of India (Borole, 1988; Rao \& Wagle, 1997; Somayajulu et al., 1999). The rate of sedimentation estimated in the northern part (off Bombay) varies from $1.8-2.5 \mathrm{~mm} \mathrm{a}^{-1}$ (at $50 \mathrm{~m}$ water depth) to $0.24 \mathrm{~mm} \mathrm{a}^{-1}$ (at $280 \mathrm{~m}$ water depth). It is about $2.2 \mathrm{~mm} \mathrm{a}^{-1}$ off Dwarka (at $280 \mathrm{~m}$ water depth) and $2.6 \mathrm{~mm} \mathrm{a}^{-1}$ off Porbandar (at $480 \mathrm{~m}$ water depth). Towards the south (off Mangalore), the estimated rates are: $0.56-0.72 \mathrm{~mm} \mathrm{a}^{-1}$ (between $35 \mathrm{~m}$ and $40 \mathrm{~m}$ water depths) and $1.0 \mathrm{~mm} \mathrm{a}^{-1}$ (at $370 \mathrm{~m}$ water depth). The sedimentation rate is about $2.6 \mathrm{~mm} \mathrm{a}^{-1}$ in the offshore region of Cochin at $590 \mathrm{~m}$ water depth. The published data broadly indicate higher sedimentation rates in the northern 


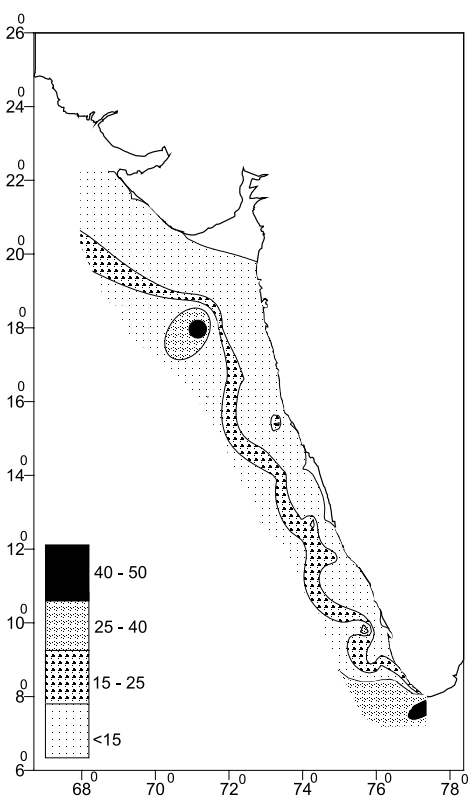

Fig. 7. Distribution of relative abundance (\%) of Limacina trochiformis in surface sediments of the western continental shelf of India.

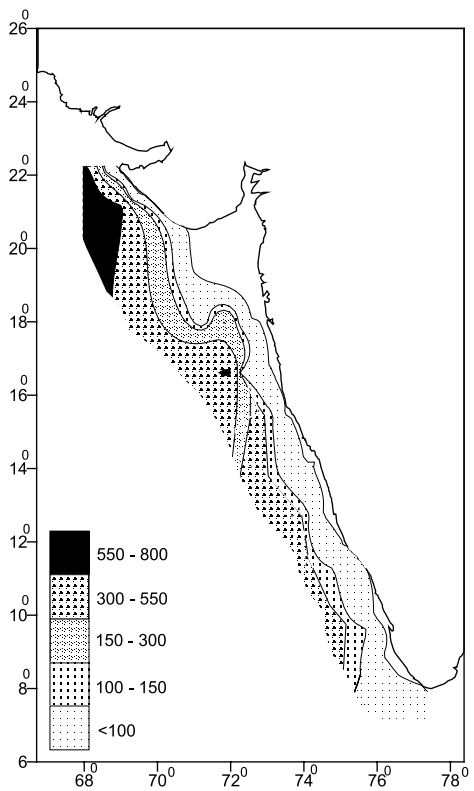

Fig. 8. Absolute abundance of Creseis chierchiae in surface sediments of the western continental shelf of India.

region, owing to a higher fluvial discharge from the larger rivers than in the central and southern parts, where sediment discharge is lesser to the shelf (Rao \& Wagle, 1997). The faunal concentration in sediments is expected to be relatively low in areas of high accumulation rate, where dilution of autochthonous biogenic sediments by terrigenous sediments is high. However, the total abundance of pteropods is found in this study to be much higher in the north as compared to the southern region with a low rate of sedimentation. Therefore, accumulation rate does not appear to be the main factor governing north-south pteropod distribution patterns in the study area. Species of

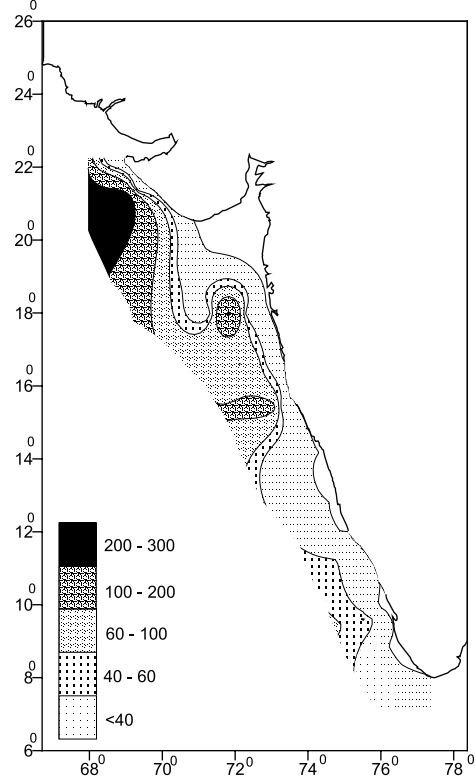

Fig. 9. Absolute abundance of Creseis acicula in surface sediments of the western continental shelf of India.

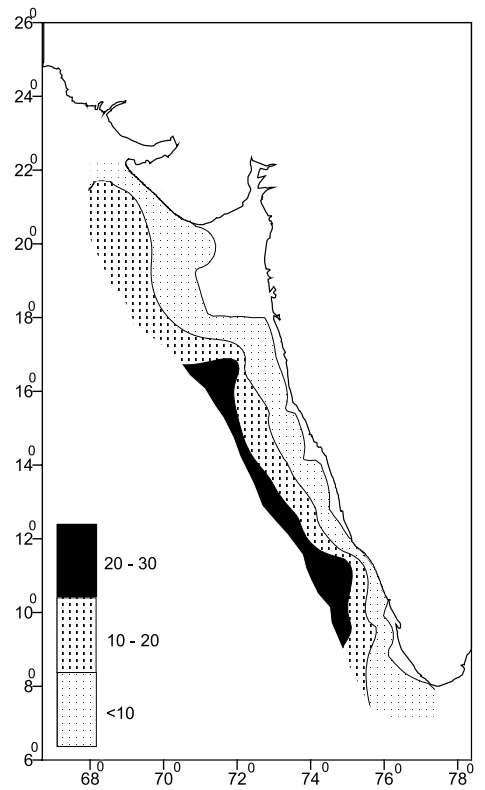

Fig. 10. Absolute abundance of Creseis virgula in surface sediments of the western continental shelf of India.

pteropods in these samples fall into the two major groups: mesopelagic (deeper-water dwellers) and epipelagic (shallow-water dwellers). The quantitative pteropod data reflect that the relative abundances of epipelagic and mesopelagic components in the assemblage vary with the water depths across the shelf. All those species recorded from $<50 \mathrm{~m}$ depths are exclusively epipelagic, whilst assemblages from $>50 \mathrm{~m}$ depths comprise both mesopelagic and epipelagic species. The abundance of mesopelagic pteropods increases with depth, which suggests that the vertical depth habit of pteropods is an important factor controlling their abundance pattern across the western continental shelf of India. 
A. D. Singh et al.

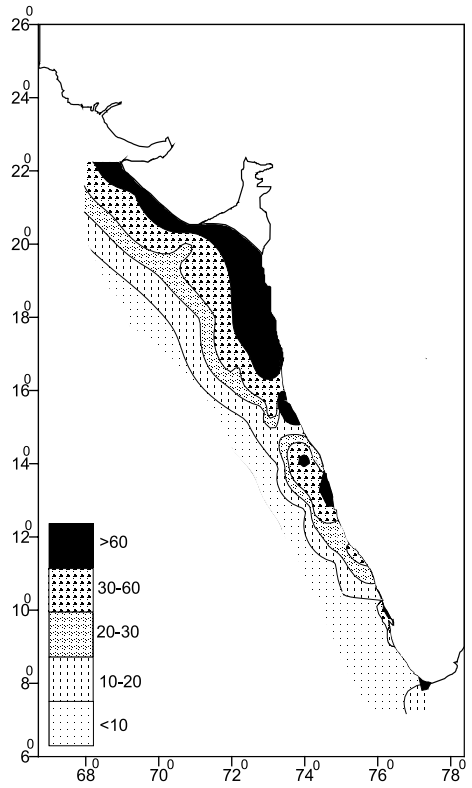

Fig. 11. Distribution of relative abundance (\%) of Creseis spp. (chierchiae + acicula) in surface sediments of the western continental shelf of India.

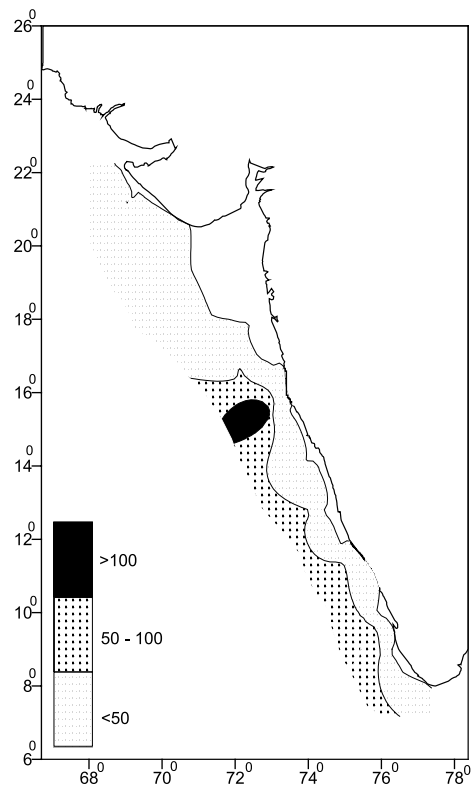

Fig. 12. Absolute abundance of Clio convexa in surface sediments of the western continental shelf of India.

Additionally, the population density of pteropods in surficial sediments can be influenced by the influx of terrigenous clastics. A lower pteropod concentration in shallow sediments $(<50 \mathrm{~m})$ may be attributed to the dilution due to high terrigenous input in near-shore areas. Beyond the inner shelf, only a minor influx of terrigenous clastics takes place, hence, the dilution effect is minimal in deeper regions (Nair \& Hashimi, 1980). A decrease in amounts of terrigenous/detrital material from the inner shelf to the outer shelf-slope region could be an additional reason for the increase in abundance of pteropods with water depth. A small patch of high concentration of pteropods on the middle

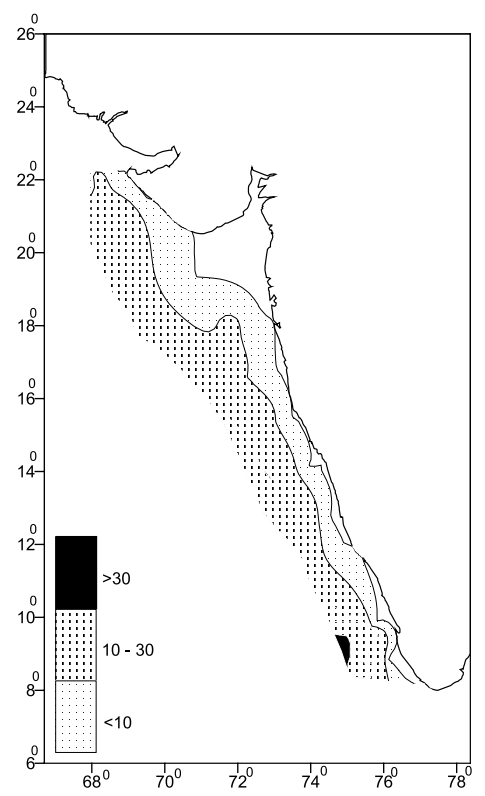

Fig. 13. Absolute abundance of Diacria quadridentata in surface sediments of the western continental shelf of India.

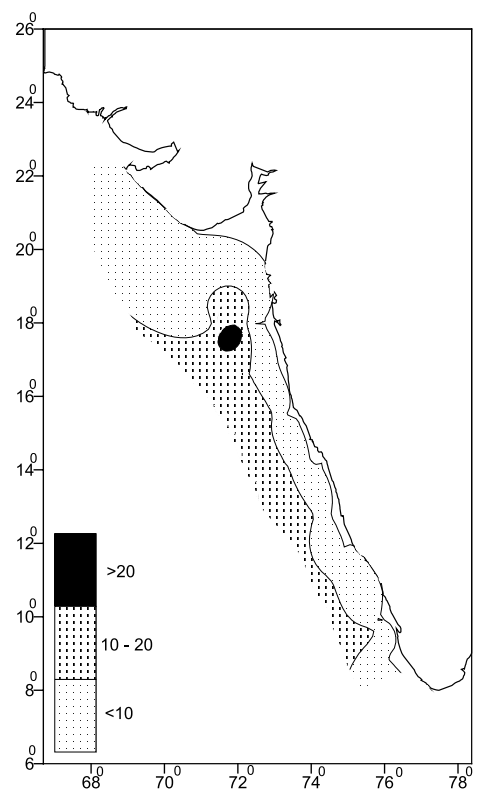

Fig. 14. Absolute abundance of Cavolinia longirostris in surface sediments of the western continental shelf of India.

shelf between Ratnagiri and Bombay may be related to the high sediment accumulation in the region, during intense hydrodynamic condition manifested by the locally centred strong tidal currents (Rao \& Wagle, 1997).

Primary productivity is another probable factor which may account for the differences in production of pteropods and their concentration in sediments. Several studies have reported a strong positive correlation between primary productivity and pteropod production in the open oceans (Berner, 1977; Berner \& Honjo, 1981; Wormuth, 1981; Deuser, 1986; Almogi-Labin et al., 1988). The eastern part of the Arabian Sea is known to be 


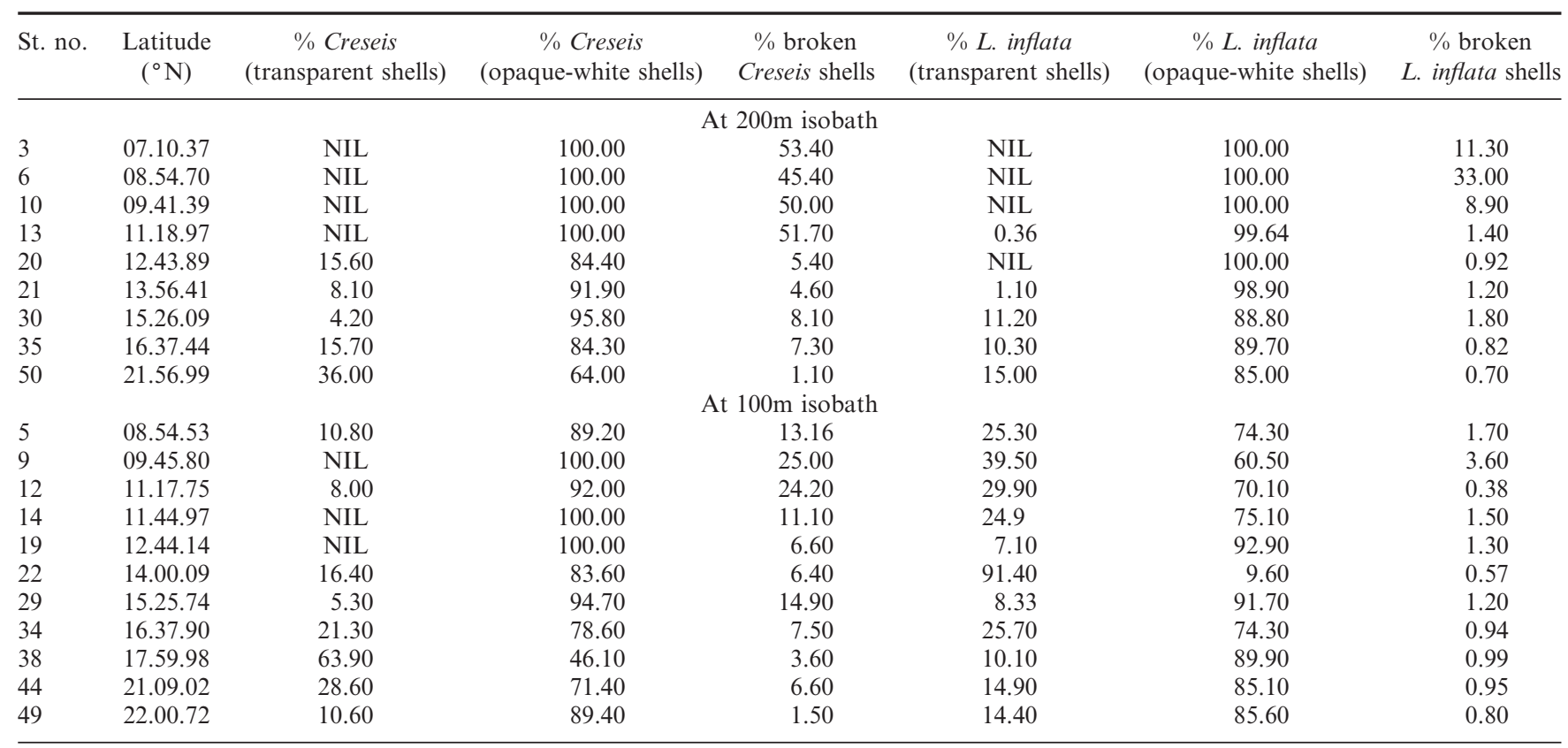

Note that Creseis acicula and C. chierchiae are more susceptible to dissolution than Limacina inflata.

Table 3. Relative abundance of transparent and opaque shells in Creseis (acicula and chierchiae) and Limacina inflata populations (only whole shells) and percentage abundance of broken shells in total L. inflata and Creseis populations (broken + whole shells) at $200 \mathrm{~m}$ and $100 \mathrm{~m}$ isobaths along the western continental shelf of India.

oligotrophic compared with the western and northern regions (Ivanova et al., 2003). In oligotrophic parts of the Red Sea, some pteropod species are found to be not associated directly with the winter productivity (Almogi-Labin, 1984). A flux study carried out by Schulz et al. (2002) does not indicate any significant correlation between the pteropod abundance and primary productivity in the northeastern Arabian Sea. In the investigated area, annual primary productivity is very high $\left(>1 \mathrm{gC} \mathrm{m}^{-2} \mathrm{~d}^{-1}\right)$ south of Cochin, as compared to the northern part of the west coast (between off Bombay and off Dwarka: $0.25 \mathrm{gC} \mathrm{m}^{-2} \mathrm{~d}^{-1}$ ) (Qasim, 1977). Productivity is moderate $\left(0.25-0.75 \mathrm{gC} \mathrm{m}^{-2}\right.$ $\mathrm{d}^{-1}$ ) on the shelf between off Bombay and off Cochin (Qasim, 1977), and the maximum abundance of total pteropods is recorded in the northern region with low surface productivity. However, pteropods occur in low numbers in offshore sediments south of Cochin where primary productivity is high.Therefore, additional factors other than productivity are responsible for the general pattern of pteropod distribution on the shelf off the west coast of India.

The annual surface water salinity in the study area varies approximately between $34 \%$ in the south and $36 \%$ in the north (Wyrtki, 1971). The majority of pteropod species encountered in this investigation have a wide range of salinity tolerance, as they are recorded frequently in high salinity waters of the Red Sea (Weikert, 1987) and also in the south China Sea, where salinity is as low as c. 30\% (Rottman, 1980). Thus, it is unlikely that the differences in absolute salinity of surface waters across, as well as along, the shelf are responsible for such a large variation in pteropod concentration as that observed between the southern and northern parts of the western Indian shelf. Instead, a prominent variation in the vertical (surface-subsurface water) salinity gradient between southern and northern regions might have influenced profoundly the abundance of pteropods in the study area. In the northern part, a negligible difference in salinity between the surface and $200 \mathrm{~m}$ depths might be favourable for most of the migratory pteropods. A high vertical salinity gradient and, hence, a steep density profile with a sharp halocline/pycnocline in the south could be an obstacle for migratory pteropods. This might have led to an overall low abundance of pteropods in the southern offshore region.

Aragonitic preservation considerably influences the pteropod contents of the sediments. Although the investigated area is above the Aragonite Compensation Depth (c. $400 \mathrm{~m}$ water depth), pteropod shells in sediments along this shelf display varying degrees of preservation. The pteropods are well preserved in shallow sediments at water depths $<100 \mathrm{~m}$. In deeper sediments, the best aragonite preservation is recorded in the northern region, while dissolution of the most delicate shells, such as $C$. chierchiae and C. acicula, occurs in the southernmost part, as evident by high numbers of damaged shells. It is suspected that a significant number of high disolution-susceptible species might have been completely dissolved, resulting in overall low concentration of total pteropods in the southern region. Perhaps, better aragonite preservation is one of the major factors for high pteropod content in sediments of the northern offshore region. The pattern of pteropod abundance in shelf sediments off the west coast of India appears to be governed by a combination of factors, including bathymetry, salinity gradient within the water column and the degree of aragonite preservation.

\section{Limacina inflata (d' Orbigny, 1836)}

$L$. inflata is the most abundant pteropod in the outer shelf-slope sediments $(>100 \mathrm{~m})$ of the western continental margin of India, 
A. D. Singh et al.
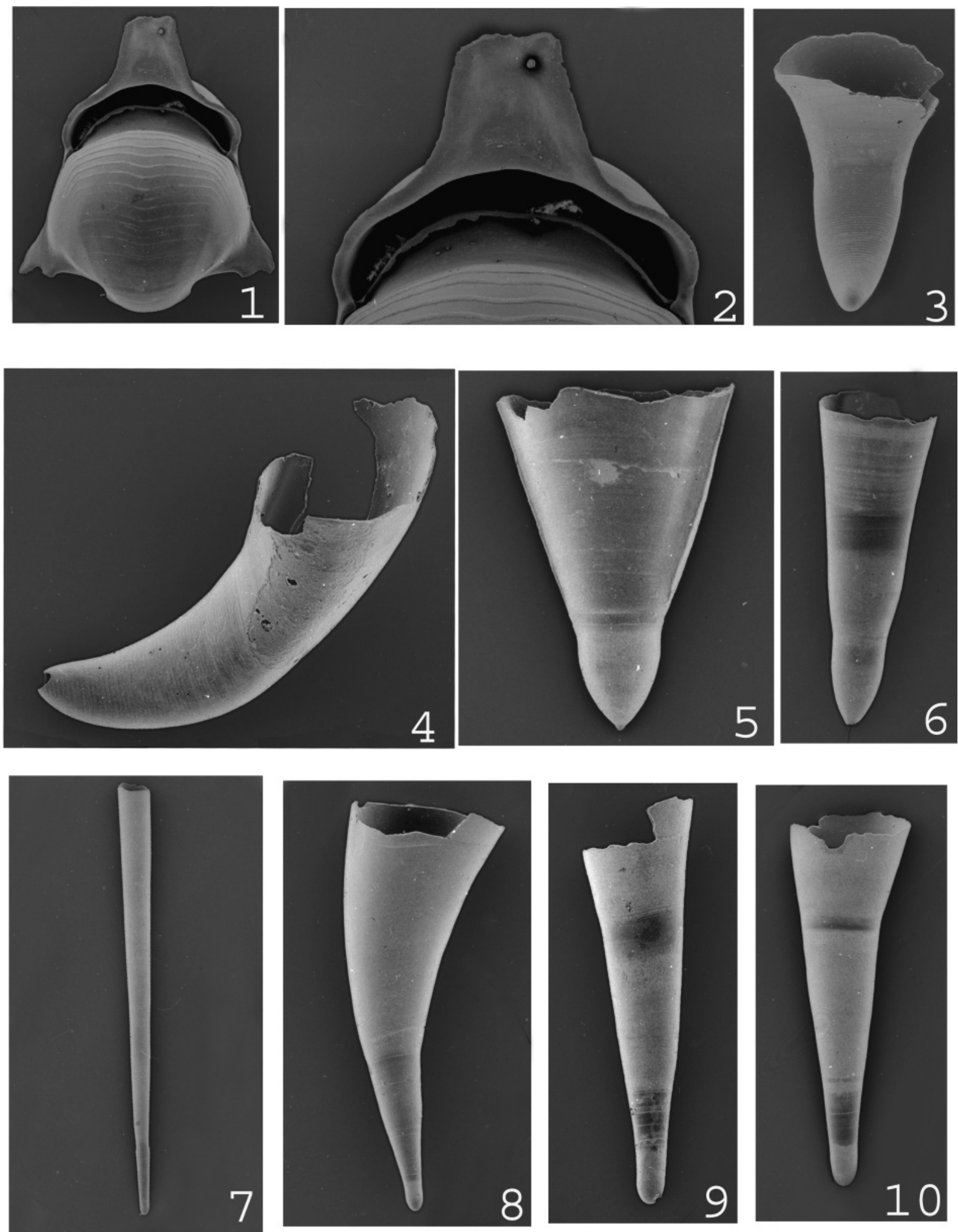

Explanation of Plate 1.

figs 1-3. Cavolinia longirostris (de Blainville): 1, apertural view, $\times 100 ; \mathbf{2}$, enlarged apertural view, $\times 420 ; 3$, embryonic part, $\times 173$. fig. 4. Cavolinia gibbosa (d'Orbigny), embryonic part, $\times 184$. fig. 5. Clio convexa (Boas), $\times 102$. fig. 6. Styliola subula (Quoy \& Gaimard), $\times 102$. figs 9 , 10. Creseis virgula $($ Rang) conica Escholtz: 9, $\times 110 ; 10, \times 117$. fig. 7. Creseis acicula $(\mathrm{Rang}), \times 104$. fig. 8. Creseis virgula $(\mathrm{Rang})$ virgula $(\mathrm{Rang}), \times 98$. 
Recent Indian pteropods
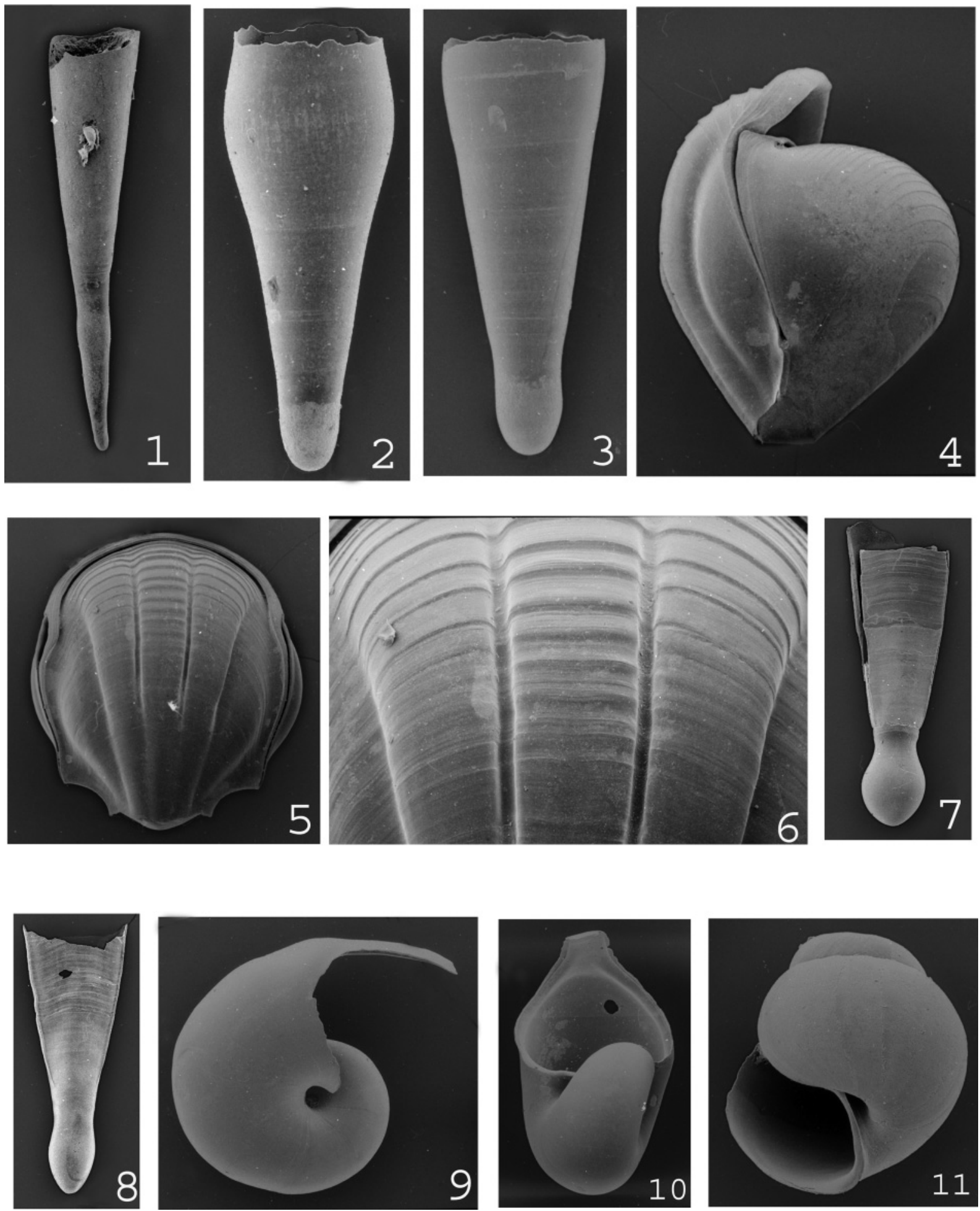

Explanation of Plate 2.

figs 1-3. Creseis chierchiae (Boas): 1, $\times 105 ; \mathbf{2}, \times 107 ; \mathbf{3}, \times 210$. figs 4-6, 8. Diacria quadridentata (de Blainville): 4, lateral view, $\times 95 ; \mathbf{5}$, dorsal view, $\times 97 ; \mathbf{6}$, enlarged view of dorsal surface, $\times 170 ; \mathbf{8}$, embryonic part, $\times 110$. fig. 7. Diacria trispinosa (de Blainville), $\times 124$. figs $9-10$. Limacina inflata (d'Orbigny): 9, umbilical view, $\times 160 ; \mathbf{1 0}$, apertural view, $\times 175$. fig. 11. Limacina trochiformis (d'Orbigny), apertural view, $\times 175$.

because it is a mesopelagic species. At shallow locations $(<50 \mathrm{~m}$ water depth) L. inflata is conspicuously absent, whilst at intermediate depths between $50 \mathrm{~m}$ and $100 \mathrm{~m}$, this species shows a gradual increase in both its absolute number and relative abundance with the bathymetry (Figs 4,5 ). This observation is in agreement with previous studies (Herman \& Rosenberg, 1969; 
Singh et al., 1998), which suggested a strong bathymetric control on the distribution of $L$. inflata in shelf sediments off the west coast of India.

A drastic increase in the abundance of $L$. inflata is noticed in sediments at $200 \mathrm{~m}$ depths within the oxygen minimum zone (OMZ) (Table 2). This species is known to proliferate in the present-day OMZ, with a minimum concentration of $c .0 .5 \mathrm{ml}$ $\mathrm{O}_{2} 1^{-1}$ in the Red Sea (Weikert, 1982, 1987). Almogi-Labin et al. (1991, 1998) opined that $L$. inflata and other mesopelagic migratory species disappeared in the Red Sea in the past when oxygen concentration decreased below $0.5 \mathrm{ml} \mathrm{O}_{2} 1^{-1}$. The western continental shelf of India is adjacent to a strong OMZ characterized by much lower oxygen concentration compared with the Red Sea. In the study area, the oxygen concentration recorded at $200 \mathrm{~m}$ water depth varies between $c .0 .2 \mathrm{ml} \mathrm{O}_{2} 1^{-1}$ in the south and $<0.05 \mathrm{ml} \mathrm{O}_{2} 1^{-1}$ in the north. High abundance of $L$. inflata in deep water implies that a very low oxygen concentration (below c. $0.5 \mathrm{ml} \mathrm{O}_{2} 1^{-1}$ ) in overlying waters does not limit the occurrence of this species. It is a fact that this migratory species adopts a variable depth habitat during its growth stages (veligers, juveniles and adults). Adults of $L$. inflata migrate much deeper in the water column and, therefore, are more susceptible to the low oxygen concentration in the OMZ. It should be noted that the majority of L. inflata specimens belong to the juvenileveliger stages $(<1000 \mu \mathrm{m})$. These smaller forms appear to be restricted in their vertical migration, preferring to live in the upper part of the water column (Almogi-Labin et al., 1988) and so may not be affected much by the intensified OMZ.

The data indicate low concentration of $L$. inflata in sediments off the southwest coast of India (south of $9^{\circ} \mathrm{N}$ ), whereas at the same water depths in the northern region it occurs in highabundance. As L. inflata is tolerant to a wide range of salinity, evident by its common occurrence in the eastern Mediterranean and the northern Red Sea (39-40\%o) and the south China Sea $(32.75 \%)$, the difference in surface water salinities between northern and southern regions probably cannot explain the distribution pattern of this species. Other potential reasons for this distribution might be: (1) a marked halocline in the southern region may be a barrier for this migratory species; (2) an almost uniform salinity profile in the northern region might be conducive for the proliferation of L. inflata; and (3) poor preservation may also have contributed to a low concentration of $L$. inflata in the southern region as compared with the north where aragonite shells are better preserved.

\section{Limacina trochiformis (d' Orbigny, 1836)}

L. trochiformis is an epipelagic taxon associated with the mixed layer in the water column (Bé \& Gilmer 1977; Wormuth, 1981; Almogi-Labin et al., 1988). The recorded temperature range of L. trochiformis in the western North Atlantic is $13.8-27.9^{\circ} \mathrm{C}$ and the salinity range is 35.5-36\% (Chen \& Bé, 1964). Rottman $(1978,1980)$ recorded this species from the Gulf of Thailand and the south China Sea at a minimum salinity of $30.72 \%$ and a maximum temperature of $30.47^{\circ} \mathrm{C}$. Therefore, the abundance of this species in surficial sediments of the western continental shelf of India is probably not controlled by the water salinity and temperature conditions. The pattern distribution demonstrates a positive correlation between bathymetry and its absolute abundance across the shelf (Fig. 6). The relative abundance of $L$. trochiformis in shallow sediments $(<100 \mathrm{~m}$ water depths) is also found to be dictated by the bathymetry (Fig. 7). Frequency drops in deeper sediments after reaching a maximum at around $100 \mathrm{~m}$ depth (Fig. 7). A low relative abundance of this taxon in outer shelf-upper slope regions is probably related to a drastic increase in contribution of $L$. inflata to pteropod population in deeper locations. Within the outer shelf south of $13^{\circ} \mathrm{N}, L$. trochiformis shows its maximum numerical abundance in sediments off Cochin (Table 2), where a weak coastal upwelling occurs during the summer monsoon (Naidu et al., 1999). This suggests that this species thrives in upwelling conditions, which has also been noted by Bé \& Gilmer (1977) and Sakthivel (1969). A moderate increase in total abundance of pteropods is noticed in these locally centred upwelling regions.

\section{Creseis chierchiae (Boas, 1886)}

C. chierchiae is an epipelagic species occurring commonly with L. trochiformis in the mixed layer. However, C. chierchiae has a wider range (a minimum salinity of $29.92 \%$ and a maximum temperature of $31.35^{\circ} \mathrm{C}$ ) and tends to inhabit shallower conditions than L. trochiformis (Frontier, 1963; Rottman, 1980). This study demonstrates a bathymetric control on the distribution of $C$. chierchiae across the shelf-upper slope off the west coast of India (Fig. 8). Its frequent occurrence is recorded from water depths greater than $50 \mathrm{~m}$, with a maximum abundance at $200 \mathrm{~m}$. A close relationship between abundance of this species and bathymetric conditions has been documented previously in the southern part of the western Indian shelf (Singh et al., 1998). It is intriguing to note that the numerical abundance of $C$. chierchiae at deeper stations is much higher in the northern region as compared with the southern part (Fig. 8). C. chierchiae is known to proliferate in low (Rottman, 1980), as well as high salinity (Almogi-Labin et al., 1991) shallow waters. Therefore, a south-north difference in surface salinity alone cannot explain satisfactorily its abundance pattern along the shelf. Instead, more stratified waters associated with the steep vertical salinity gradient could be a plausible cause for the low abundance of this taxon in the southern region, while high abundances in the northern part may be attributed to the less stratified water column.

As $C$. chierchiae is one of the most dissolution susceptible species, preservation in sediments will obviously have a significant influence on its abundance pattern. The record reflects best preservation of Creseis (chierchiae and acicula) in the north with anoxic bottom conditions. On the contrary, shells of Creseis are poorly preserved in the southern part where oxygen concentration is high enough (between $0.1 \mathrm{ml} \mathrm{O}_{2} 1^{-1}$ and $1.0 \mathrm{ml}$ $\mathrm{O}_{2} 1^{-1}$ ) to cause dissolution of these delicate species. Therefore, high fragmentation or even complete elimination of many shells of this most delicate taxon due to dissolution might be another important factor causing its low concentration in the southern region.

\section{Creseis acicula (Rang, 1828)}

C. acicula is another epipelagic species occurring commonly along with $C$. chierchiae in the mixed layer of the water column. This taxon is an important contributor to the Creseis population in the shelf sediments off the west coast of India. C. acicula occurs in sediments from the shallowest regions of the inner 
shelf (around $30 \mathrm{~m}$ water depth). Previous studies on living pteropods suggest that this species prefers the shallowest depth habitat amongst all epipelagic pteropods (Wormelle, 1962; Frontier, 1973; Rottman, 1980).

The pattern distribution of $C$. acicula along the shelf is almost similar to that of $C$. chierchiae, with higher concentrations in outer shelf-slope sediments of the northern part of the western continental margin (Fig. 9). The numerical abundance of this taxon in the southern offshore regions is found to be very low. C. acicula occurs abundantly in the Persian Gulf, the Red Sea and the Mediterranean Sea (Herman, 1971; Almogi-Labin \& Reiss, 1977; Reiss et al., 1980). Van der Spoel (1967) recorded salinity and temperature ranges of this taxon as 35.5-36.7\%o and $10-27.9^{\circ} \mathrm{C}$, respectively. Sakthivel (1969) and Rottman (1980) found abundant occurrences of this species, together with $C$. chierchiae, in low salinity waters of the Bay of Bengal and the south China Sea, respectively. Thus, C. acicula has tolerance to a wide range of salinity $(30-55 \%)$. Therefore, it is unlikely that surface water salinity is responsible for such a large-scale variation in abundance of $C$. acicula between the south and the north along the western continental shelf of India. Instead, it appears to be related to the conspicuous differences in water column stratification linked with the vertical salinity gradient between the south and north. Additionally, as observed in the case of $C$. chierchiae, a varying degree of aragonite preservation along the shelf might have also influenced the abundance patterns of $C$. acicula. Thus, plausible reasons for the very high concentration of $C$. acicula in the northern region are a better preservation potential in sediments and less stratified overlying waters. Conversely, its low abundance in the southern offshore region might also be attributed to the very poor shell preservation and presence of more stratified waters in the area.

\section{Creseis virgula (Rang, 1828)}

C. virgula is the least abundant epipelagic pteropod in surficial sediments of the western continental shelf of India. The distribution map of $C$. virgula includes two subspecies, $C$. virgula virgula (Rang, 1828) and $C$. virgula (Rang, 1828) conica Escholtz, 1829. The total abundance of the species is higher in the shelf edge to upper slope locations (Fig. 10). This taxon is at its rarest in sediments less than $100 \mathrm{~m}$ water depth. Its most frequent to abundant occurrence has been reported from the Mediterranean Sea (Almogi-Labin \& Reiss, 1977), equatorial Pacific (Fager \& McGowan, 1963), the Somali coast, the Bay of Bengal and the Gulf of Oman (Sakthivel, 1969). In these regions, C. virgula commonly occurs with C. acicula and both the species show an almost identical distribution pattern. In contrast to other epipelagic pteropods (C. acicula, C. chierchiae and $L$. trochiformis), the reason for its rare occurrence in the study area is not clear, but may be associated with its adjustment to ecological limitations in the mixed layer. C. virgula is known to have preference for strong illumination (Stubbings, 1938), also a wide range of variation in the temperature $\left(7-31^{\circ} \mathrm{C}\right)$ and salinity (34.95-36.68\%) between subspecies has been recorded by Williams (1972) and Chen \& Bé (1964). Rottman (1978, 1980) recorded a maximum occurrence of $C$. virgula virgula and $C$. virgula conica in less saline waters $(30.72 \%$ ) of the south China and Java seas within the depth range 51-100 $\mathrm{m}$.
Earlier studies on pteropod assemblages in surficial sediments from certain parts of the western continental shelf off India suggested a bathymetric control on relative abundance of Creseis spp. (Herman \& Rosenberg, 1969; Singh et al., 1998). An attempt is made here to record the relationship between bathymetry and variation in relative abundance of Creseis spp. in pteropod populations across the entire western Indian shelf (Fig. 11). To attain more meaningful results, only two more common shallow-water dweller Creseis species (acicula and chierchiae) were considered, omitting $C$. virgula, which is more characteristic of the open sea, commonly occurring in sediments deeper than $100 \mathrm{~m}$. The data reveal a converse relationship between bathymetry and percent frequency variations across the shelf (Fig. 11). However, the range of variation in relative abundance of Creseis spp. across the shelf is different from south to north, which might be related to varying hydrographic conditions and the preservation state of aragonite in shelf sediments along the west coast of India.

\section{Clio convexa (Boas, 1886)}

C. convexa is a mesopelagic, migratory species and it is very rare in the inner shelf sediments, but exhibits a high abundance in deeper regions greater than $100 \mathrm{~m}$ water depth (Fig. 12). The near absence of $C$. convexa in shallow locations may be related to its depth habitat, whilst the high relative abundance of $C$. convexa (c. 14\%) is recorded at $100 \mathrm{~m}$ and $200 \mathrm{~m}$ depths in southern offshore region, but it becomes very low in outer shelf-slope sediments of the northernmost part of the west coast (Table 2). This species is reported to live in Red Sea waters with a salinity range of 38.5-40.5\% (Hemleben et al., 1996; Almogi-Labin et al., 1998). C. convexa also occurs abundantly in the south China Sea at a minimum salinity of $32.7 \%$ (Rottman, 1980). The available data on the salinity range of $C$. convexa suggest that the surface salinity of offshore waters, which varies between $33 \%$ and $36 \%$ in the study area, cannot explain the distribution pattern of this species. Almogi-Labin et al. (1991) observed a close relationship between abundance of the mesopelagic (migratory) pteropods and oxygen-depleted environment associated with the OMZ in the Red Sea. According to Weikert $(1982,1987)$ C. convexa migrates deeper down to the OMZ. This species disappears from the Red Sea when the OMZ becomes more intensified and more extended vertically (Almogi-Labin et al., 1998). In the study area, a pronounced OMZ develops below $100 \mathrm{~m}$, where the oxygen content decreases rapidly. The subsurface oxygen concentration within the OMZ is lowest in the north and highest in the south (Table 1). Therefore, variation in the strength of the OMZ might be a factor controlling the abundance pattern of this species. In the northern offshore region, where the OMZ is more enhanced, C. convexa occurs in low numbers. Its abundance increases in the relatively weaker $\mathrm{OMZ}$ of the southern offshore region. It is worth recording the effect of intensified OMZ on the occurrence of another mesopelagic (migratory) species, Styliola subula. This species is characteristically absent in the investigation area, except for a single record of a single specimen from the south off Cape Comorin. A near-total absence of $S$. subula in the pteropod population might be related to the unique subsurface $\mathrm{OMZ}$ prevailing in the area, as suggested by Sakthivel (1973b). 
Diacria quadridentata (de Blainville, 1821) and Cavolinia longirostris (de Blainville, 1821)

D. quadridentata occurs infrequently in the shelf sediments off the west coast of India. This species is known to be more stenothermic than other Diacria species (Bé \& Gilmer, 1977). With respect to depth habitat, this species was reported to occupy both shallow and deep waters. According to Stubbings (1938), D. quadridentata exhibits diurnal vertical migration, with a mean night level at $700 \mathrm{~m}$ in the Arabian Sea. However, Wormelle (1962) recorded this species from shallower depths in the North Atlantic. Rottman $(1978,1980)$ considered this species as less indicative of oceanic conditions than the typical mesopelagic pteropods, such as Limacina inflata, Clio convexa and Styliola subula.

In the study area, D. quadridentata is conspicuously absent in the sediments of the southernmost offshore region, lying below low salinity waters (Fig. 13), and shows a maximum concentration at $200 \mathrm{~m}$. Only a few individuals $\left(<3\right.$ specimens $\left.\mathrm{g}^{-1}\right)$ of this species are recovered from $30 \mathrm{~m}$ to $100 \mathrm{~m}$ water depths between $9^{\circ} \mathrm{N}$ and $12^{\circ} \mathrm{N}$, while in the northern part the number is slightly higher (Table 2). According to Williams (1972) the temperature and salinity ranges of $D$. quadridentata are $19.0^{\circ} \mathrm{C}$ to $25.5^{\circ} \mathrm{C}$ and $35.7 \%$ to $36.25 \%$, respectively. The surface salinity at which this species was found in the Gulf of Thailand was always greater than $32 \%$ and it was absent in the shallow, low salinity regions (Rottman, 1980). Rottman (1978) also recorded a positive correlation between abundance of $D$. quadridentata and salinity, which suggests that this species is less tolerant to low salinity environments. In the southern offshore region of the study area, the surface salinity drops to c. $32 \%$ (Wyrtki, 1971) during the NE monsoon season due to inflow of the low salinity waters from the Bay of Bengal. Therefore, the presence of low salinity waters may be a plausible cause for a total absence of this species in the sediments off Cape Comorin and Trivandrum.

The distribution pattern of Cavolinia longirostris in sediments off the west coast of India is almost similar to that of $D$. quadridentata (Fig. 14). A common occurrence of C. longirostris in the tropical Indian Ocean was reported previously by Sakthivel (1969). Van der Spoel (1967) observed a temperature range of $17.4-27.8^{\circ} \mathrm{C}$ and a salinity range of $36.2-36.83 \%$ or this species. Salinity could be a factor controlling the abundance pattern of $C$. longirostris in the investigation area. Moreover, low surface water salinity conditions alone cannot be invoked as a reason for the total absence of this species from the southernmost part of the western continental shelf of India; for example, this species has been reported from the low salinity waters of the Bay of Bengal (Sakthivel, 1969) and the Gulf of Thailand (Rottman, 1978).

\section{CONCLUSIONS}

Pteropod assemblages of 50 surficial sediment samples covering the entire shelf were analysed both qualitatively and quantitatively and the distribution of eight significant species was mapped. The assemblages are characterized by low diversity and composed of both epipelagic and mesopelagic forms. Most of the species encountered are known to have a wide range of salinity tolerance. The preservation state of pteropod shells is found to be better in the north compared with the south. In the southern region, dissolution causes substantial damage, or even elimination of many shells of susceptible species.

The faunal pattern shows that the absolute abundance of pteropods in surficial sediments increases across the shelf with bathymetry and along the shelf the abundance is much higher in the north than compared with the south. Of the mesopelagic (migratory) pteropods, Limacina inflata is the most abundant taxon. There is good bathymetric control on its relative and absolute abundances between $50 \mathrm{~m}$ and $100 \mathrm{~m}$ depths. The north-south variation in the vertical salinity gradient also appears to have significant influence on the abundance pattern of L. inflata. Clio convexa is another important mesopelagic (migratory) species, showing its maximum occurrence in deeper regions greater than $100 \mathrm{~m}$ water depth. Its relative abundance is found to be higher in the southernmost offshore region where the OMZ is relatively weaker than the northern part. Diacria quadridentata and Cavolinia longirostris are not so frequent in shelf sediments. L. trochiformis is the most abundant epipelagic species in shelf sediments and there is a positive correlation between the bathymetry and its numerical abundance across the shelf. A moderate increase in its abundance in areas of coastal upwelling suggests a preference for upwelling conditions. Other epipelagic species, $C$. chierchiae and $C$. acicula, are the main contributors to the Creseis population. This study demonstrates a significant negative rank correlation between their relative abundances and water depths. Their high abundances in the north are probably attributed to the presence of less stratified waters and better shell preservation, whilst a low abundance of these species in the south may be related to the more stratified water column and poor preservation condition. Overall, this study reveals that the distribution patterns of pteropods in shelf sediments off the west coast of India are governed by a combination of factors mainly related to bathymetry, hydrography and aragonite preservation condition.

\section{ACKNOWLEDGEMENTS}

This work was supported by the Department of Ocean Development, New Delhi (Grant No. DOD/11-MRDF/4/2/UNI/97). The OSTC, Mangalore University through which the research project is administered, is acknowledged for its support. NRN thanks the Council of Scientific and Industrial Research, New Delhi for financial assistance in the form of a Senior Research Fellowship. The authors are grateful to anonymous reviewers for reviewing the manuscript thoroughly and for many helpful comments. ADS thanks CMLRE for providing samples.

\section{Manuscript received 6 December 2002 Manuscript accepted 13 July 2004}

\section{REFERENCES}

Almogi-Labin, A. 1982. Stratigraphic and paleoceanographic significance of Late Quaternary pteropods from deep-sea cores in the Gulf of Aqaba (Elat) and northernmost Red Sea. Marine Micropaleontology, 7: 53-72.

Almogi-Labin, A. 1984. Population dynamics of planktic foraminifera and pteropoda - Gulf of Aqaba, Red Sea. Proceedings Koninklijke Nederlandse Akademie Wetenschappen, 87: 481-511.

Almogi-Labin, A. \& Reiss, Z. 1977. Quaternary pteropods from Israel. Revista Española de Micropaleontologia, 9 (1): 5-48. 
Almogi-Labin, A., Luz, B. \& Duplessey, J.C. 1986. Quaternary paleoceanography, pteropod preservation and stable isotope record of the Red Sea. Palaeogeography, Palaeoclimatology, Palaeoecology, 57: 195-211.

Almogi-Labin, A., Hemleben, C. \& Deuser, W.G. 1988. Seasonal variation in the flux of euthecosomatous pteropods collected in a deep sediment trap in the Sargasso Sea. Deep Sea Research, 35: 441-464.

Almogi-Labin, A., Hemleben, C., Meischner, D. \& Erlenkeuser, H. 1991. Paleoenvironmental events during the last 13,000 years in the Central Red Sea as recorded by pteropoda. Paleoceanography, 6 83-98.

Almogi-Labin, A., Hemleben, C. \& Meischner, D. 1998. Carbonate preservation and climatic changes in the central Red Sea during the last $380 \mathrm{kyr}$ as recorded by pteropods. Marine Micropaleontology, 33: $87-107$.

Auras-Schudnagies, A., Kroon, D., Ganssen, G., Hemleben, C. \& Van Hinte, J.E. 1989. Distributional pattern of planktonic foraminifers and pteropods in surface waters and top core sediments of the Red Sea, and adjacent areas controlled by the monsoonal regime and other ecological factors. Deep Sea Research, 36: 1515-1533.

Bathmann, U.V., Noji, T.T. \& Bodungen, B.V. 1991. Sedimentation of pteropods in the Norwegian Sea in autumn. Deep Sea Research, 38: 1341-1360.

Berner, R.A. 1977. Sedimentation and dissolution of pteropods in the ocean. In: Anderson, N.R. \& Malahaff, A. (Eds), The fate of fossil fuel CO2 in the Oceans. Plenum, New York, 243-260.

Berner, R.A. \& Honjo, S. 1981. Pelagic sedimentation of aragonite: Its geochemical significance. Science, 211: 940-942.

Blainville, M.H. de 1821. Hyale, Hyalaea (Malacoz.). Dictionnaire des Sciences Naturelles, 22. Le Normant, Paris, 65-83.

Boas, J.E.V. 1886. Spolia Atlantica. Bidrag til Pteropodernes. Morfologi og systematic samt til Kundskaben om deres geografiske Udbredelse. Kongelige Danske Videnskabernes Selskabs Skrifter, 6 Raekke, naturvidenskabeling og mathematisk Afdeling, 4: 1-231.

Borole, D.V. 1988. Clay sediments accumulation rates on the monsoon dominated western continental shelf and slope regions. Marine Geology, 82: 285-291.

Byrne, R.H., Acker, J.G., Betzer, P.R., Feely, R.A. \& Cates, M.H. 1984 Water column dissolution of aragonite in the Pacific Ocean. Nature, 312: $321-326$

Bé, A.W.H. \& Gilmer, R.W. 1977. A zoogeographic and taxonomic review of euthecosomatous pteropoda. In: Ramsay, A.T.S. (Ed.), Oceanic Micropaleontology, 1. Academic Press, New York 733-808.

Chen, Ch. 1969. Pteropods in the Hot Brine sediments of the Red Sea. In: Degens, E.T. \& Ross, D.A. (Eds), Hot Brines and Recent Heavy Metal Deposits in the Red Sea. Springer, New York, 313-316.

Chen, Ch. \& Bé, A.W.H. 1964. Seasonal distribution of Euthecosomatous Pteropods in the Surface Waters of five Stations in the western North Atlantic. Bulletin of Marine Science of Gulf of Caribbean, 14 (2): 185-220.

Darbyshire, M. 1967. The surface waters off the coast of Kerala, southwest India. Deep Sea Research, 14 (3): 295-320.

Deuser, W.G. 1986. Seasonal and interannual variations in deep-water particle fluxes in the Sargasso Sea and their relation to surface hydrography. Deep Sea Research, 33: 225-246.

Deuser, W.G., Ross, E.H. \& Waterman, L.S. 1976. Glacial and pluvial periods: Their relationship revealed by Pleistocene sediments of the Red Sea and Gulf of Aden. Science, 191: 1168-1170.

Fager, E.W. \& McGowan, J.A. 1963. Zooplankton species groups in the North Pacific. Science, 140 (3566): 453-460.

Frontier, S. 1963. Présence de Creseis chierchiae (Boas) dans 1'Océan Indian. Cahiers ORSTOM, Sérié Océanographaé, 6: 229-232.

Frontier, S. 1973. Zooplancton de la région de Nosy-Bé. VI. Pteropodes, Hétéropodes. Premiere partie: espéces holoneritiques et néritiquesinternes (Contribution a' l'étude d'une baie eutrophique tropicale). Cahiers ORSTOM, Sérié Océanographaé, 11 (3): 273-289.

Gerhardt, S., Groth, H., Ruhlemann, C. \& Henrich, R. 2000. Aragonite preservation in late Quaternary sediment cores on the Brazilian Continental Slope: implications for intermediate water circulation. International Journal of Earth Sciences, 88 (4): 607-618.
Hashimi, N.H. \& Nair, R.R. 1976. Carbonate components in the coarse fraction of western continental shelf (Northern part) of India. Indian Journal of Marine Sciences, 5: 51-57.

Hemleben, Ch., Meischner, D., Zahn, R., Almogi-Labin, A., Erlenkeuser, H. \& Hiller, B. 1996. Three hundred eighty thousand year long stable isotope and faunal records from the Red Sea: Influence of global sea level change on hydrography. Paleoceanography, 11: 147-156.

Herman, Y. 1968. Evidence of climatic changes in Red Sea cores. In: Morrison, R.B. \& Wright, H.E. (Eds), Means of correlation of Quaternary successions. Proceedings of VII Congress International Association for Quaternary Research, 8. Utah University Press, Salt Lake City, UT, 325-348.

Herman, Y. 1971. Vertical and horizontal distribution of pteropods in Quaternary sequences. In: Funnel, B.M. \& Reidel, W.R. (Eds), The Micropalaeontology of Oceans. Cambridge University Press, London, 463-486.

Herman, Y. \& Rosenberg, P.E. 1969. Pteropods as bathymetric indicators. Marine Geology, 7: 169-173.

Ivanova, E.V. 1982. Biostratigraphy of the Late Quaternary Red Sea Sediments and some paleogeographic reconstructions. Geologiya morey iokeanov, tezisy dokladov $V$ Vsesoyuz. Shkoly morskoy geologiyi, 1. Akademii Nauk SSSR, Moskva, 41-42 (in Russian).

Ivanova, E.V. 1985. Late Quaternary biostratigraphy and paleotemperatures of the Red Sea and the Gulf of Aden based on planktic foraminifera and pteropods. Marine Micropaleontology, 9: 335-364.

Ivanova, E.V., Schiebel, R., Singh, A.D., Schmield, G., Niebler, H.S. \& Hemleben, Ch. 2003. Primary production in the Arabian Sea during the last 135,000 years. Palaeogeography Palaeoclimatology Palaeoecology, 197: 61-82.

Jasper, J.P. \& Deuser, W.G. 1993. Annual cycles of mass flux and isotopic composition of pteropod shells settling into the deep Sargasso Sea. Deep Sea Research, 40: 653-669.

Kalberer, M., Fischer, G., Pätzold, J., Donner, B., Segl, M. \& Wefer, G. 1993. Seasonal sedimentation and stable isotope records of pteropods off Cap Blanc. Marine Geology, 113: 305-320.

Levitus, S. 1982. Climatological Atlas of the World Ocean. National Oceanic and Atmospheric Administration Professional Paper, 13: $173 \mathrm{pp}$.

Luz, B. \& Reiss, Z. 1983. Stable carbon isotopes in Quaternary foraminifera from the Gulf of Aqaba (Elat) Red Sea. Utrecht Micropalaeontology Bulletin, 30: 129-140.

Naidu, P.D., Ramesh Kumar, M.R. \& Ramesh Babu, V. 1999. Time and space variations of monsoonal upwelling along the west and east coast of India. Continental Shelf Research, 19: 559-572.

Nair, R.R. \& Hashimi, N.H. 1980. Holocene climatic inferences from the sediments of the Western Indian continental shelf. Proceedings Indian Academy of Sciences (Earth and Planetary Sciences), 89: 299-315.

Orbigny, A.d. 1836. Mollusques. Voyage dans I'Amérique méridionale execute pendant les années 1826-1833, 5(3). Bertrand, Paris, 49-184.

Qasim, S.Z. 1977. Biological productivity of the Indian Ocean. Indian Journal of Marine Sciences, 73: 330-350.

Ramsamy, G. \& Rao, K.L.N. 1980. Geology of the continental shelf of the west coast of India. In: Miall, A.D. (Ed.), Facts and Principles of World Petroleum occurrences. Canadian Society for Petroleum Geologists Memoir, 6: 801-821.

Rang, P.C.A.L. 1828. Notice sur quelques mollusques nouveaux appartenant au genre Cléodore, et établissement et monographie du sous-genre Créseis. Annales des Sciences Naturelles, 13: 302-319.

Rao, V.P. \& Wagle, B.G. 1997. Geomorphology and surficial geology of the western continental shelf and slope of India: A review. Current Science, 73 (40): 330-350.

Reiss, Z., Luz, B., Almogi-Labin, A., Halicz, E., Winter, A., Wolf, M. \& Ross, D.A. 1980. Late Quaternary paleoceanography of the Gulf of Aqaba (Elat), Red Sea. Quaternary Research, 14: 294-308.

Rosenberg-Herman, Y. 1965. Etudes des sediments quaternaires de la Mer Rouge. Thésis, A(1123). University of Paris, Paris, 339-430.

Rottman, M.L. 1978. Species association of planktonic foraminifera and zooplankton in the south China and Java Sea. Journal of Foraminiferal Research, 8 (6): 350-359. 
Rottman, M.L. 1980. Net tow and surface sediment distribution of pteropods in the South China Sea region: comparison and oceanographic implications. Marine Micropaleontology, 5: 71-110.

Sakthivel, M. 1969. A preliminary report on the distribution and relative abundance of Euthecosomata with a note on the seasonal variation of Limacina species in the Indian Ocean. Bulletin of National Institute of Science, India, 38: 700-717.

Sakthivel, M. 1973a. Studies on Limacina inflata d'Orbigny (Thecosomata, Gastropoda) in the Indian Ocean. In: Zeitzschel, B. \& Gerlach, S.A. (Eds), The Biology of the Indian Ocean. Ecological Studies, 3. Springer, Berlin, Heidelberg, New York, 383-397.

Sakthivel, M. 1973b. Biogeographical change in the latitudinal boundary of a bisubtropical pteropod Styliola subula (Quoy and Gaimard) in the Indian Ocean. In: Zeitzschel, B. \& Gerlach, S.A. (Eds), The Biology of the Indian Ocean. Ecological Studies, 3. Springer, Berlin, Heidelberg, New York, 401-404.

Schulz, H., von Rad, U. \& Ittekkot, V. 2002. Planktic foraminifera, particle flux and oceanic productivity off Pakistan, NE Arabian Sea: modern analogues and application to the paleo record. In: Clift, P.D., Kroon, D., Gaedicke, C. \& Craig, J. (Eds), The Tectonic and Climatic Evolution of the Arabian Sea Region. Geological Society, London, Special Publications, 195: 499-516.

Singh, A.D. \& Rajarama, K.N. 1997. Distribution of pteropods in surface sediments from the continental shelf off North Kerala. Journal of Geological Society of India, 49: 81-84.

Singh, A.D., Rajarama, K.N., Ramachandran, K.K., Suchindan, G.K. \& Samsuddin, M. 1998. Pteropods as bathometers: a case study from the continental shelf off Kerala coast, India. Current Science, 75 (6): 620-623.

Singh, A.D., Ramachandran, K.K., Samsuddin, M., Nisha, N.R. \& Haneeshkumar, V. 2001. Significance of pteropods in deciphering the late Quaternary sea-level history along the southwestern Indian shelf. Geo-Marine Letters, 20 (4): 243-251.

Somayajulu, B.L.K., Bhushan, R., Sarkar, A., Burr, G.S. \& Jull, A.J.T. 1999. Sediment deposition rates on the continental margins of the eastern Arabian Sea using 210Pb, 137Cs and 14C. The Science of the Total Environment, 237/238: 429-439.

Stubbings, H.G. 1938. Pteropoda, The John Murray Expedition 1933-1934. Scientific Report, 5 (2): 3-33.

Sverdrup, H.U., Johnson, M.W. \& Fleming, R.H. 1942. The Oceans, their Physics, Chemistry and General Biology. Prentice-Hall, New York, $1087 \mathrm{pp}$.

Van der Spoel, S. 1967. Euthecosomata, a group with remarkable development stages (Gastropoda, Pteropoda). J. Noorduijn en Zoon N.V, Gorinchem, 375pp.

Vinogradov, M.Y.E. 1961. Food sources for the deep-water fauna. Speed of decomposition of dead Pteropoda. Doklady Akademii Nauk SSSR, 138: 1439-1442.

Weikert, H. 1982. The vertical distribution of zooplankton in relation to habitat zones in the area of the Atlantis II Deep, central Red Sea. Marine Ecology Progress Series, 8: 129-143.

Weikert, H. 1987. Plankton and the pelagic environment in the Red Sea. In: Edwards, A.J. \& Head, S.M. (Eds), Red Sea (Key Environments). Pergamon, New York, 90-111.

Williams, S.W. 1972. The temporal and spatial variation of selected thecosomatous pteropods from the Florida Middle Ground. MSc Thesis. Florida State University, 203pp.

Winter, A., Almogi-Labin, A., Erez, Y., Halicz, E., Luz, B. \& Reiss, Z. 1983. Salinity tolerance of marine organisms deduced from Red Sea Quaternary record. Marine Geology, 53: M17-M22.

Wormelle, R.L. 1962. A survey of the standing crop of plankton of the Florida Current. VI. A study of the distribution of the pteropods of the Florida Current. Bulletin of Marine Science of Gulf of Caribbea, 12 (1): $95-136$

Wormuth, J.H. 1981. Vertical distribution and diel migrations of Euthecosomata in the northwest Sargasso Sea. Deep Sea Research, 28 (12): 1493-1515.

Wyrtki, K. 1971. Oceanographic Atlas of the International Indian Ocean Expedition. National Science Foundation, Washington D.C, 531pp. 